


\section{ILIINOIS}

atural Fistory Survey BULIETIN

\section{Comparative Uptake and Biodegradability of DDT and Methoxychlor by Aquatic Organisms}

ah A. Reinbold

P. Kapoor

n F. Childers

N. Bruce

t L. Metcalf 
BOARD OF NATURAL RESOURCES AND CONSERVATION

William H. Robinson, Chairman; THomas PARK, Ṕh.D., Biology: L. L. Sloss, Ph.D. Geology; ROGER ADAMS, Ph.D.,D.Sc., Chemistry; ROBERT H.' ANDERSON, B.S.C.E., Engineering; C̈IIARLES E, OLMSTED, Ph.D., Forestry: W. L. EveriTT, E.E., Ph.D., Representing the President of the University of Illinois; ROGER E. BEYLER, Ph.D., kepresenting the President of Southern Illinois University.

\section{NATURAL HISTORY SURVEY DIVISION, Urbana, Illinois}

\section{SCIENTIFIC AND TECHNICAL STAFF}

GEORGE SPRUGEL, JR., Ph.D., Chief

Alice P. CAMPBell, B.A., Secretary to the Chief

Sectian af Ecanomic Entomology

WilliaM H. LUCKMIANN, Ph.D., Entomologist and Heact

WiLlis N. BRUCE, Ph.D., Entomologist

WAYNE L. HOWE, Ph.D., Entomalogist

STEVENSON MOORE, III, Ph.D., Entomologist, Extension

Howard B. PETTY, Ph.D., Entomologist, Extension

JAIIES E. APPLEBY, Ph.D., Associate Entamologist

EDWARD J. ARMiruST, Ph.D., Associate Entomologist

MIarcos KOGAN, Ph.D.. Associate Entomotogist

JosePH V. MaDnox, Ph.D., Assaciate Entomologist

RoNald H. Meyer, Ph.D., Associate Entomologist

ROBERT D. PAUSCH, Ph.D., Associate Entomol-

RALPH E. SECHRIEST, Ph.D., Associate Entomol-

GEORGE L. GODFREY, Ph.D., Assistant Entomolo-

Clarence E. WHITE, B.S., Assistant Entamologist

KEUN S. PARK, M.S., Assistant Chemist

SUE E. WATKINS, Supervisory Assistant

Roscoe Randell, Ph.D., A ssistant Professar, Extension

DONALO E. KUHLMAN, Ph.D., Instructor, Extension

TIII COOLEY, M.A., A ssistant Specialist, Extension

JEAN G. WILSON, B.A. Supervisory Assistant

MARTHA P. NICHOLS, M.S., Research Assistant

KETURAH REINBOLD, M.S., Research Assistant

LOWELL DAVIS, Technical Assistant

NANCY D. DEWITT, B.S., Technical Assistant

MARCIA JANES, B.S., Technical Assistant

LU-PING KAN, M.S. Technical Assistant

MARIE MONKMAN, M.S., Technical Assistant

STEPHEN ROBERTS, B.S., Technical Assistant

DOUGLAS K. SELL, B.S., Teclinical Assistant

JOHN T. SHAW, B.S., Technical Assistant

Section of Botany and

Plant Pathology

J. CEDRIC CARTER, Ph.D., Plant Pathologist and Head

ROBERT A. EverS, Ph.D., Botanist

JUNIUS L. ForsBerg, Ph.D., Plant Pathologist

EUGENE B. HIMELICK, Ph.D., Plant Pathalogist

R. DAN NEELY, Ph.D., Plant Pathologist

D. F. SCHOENEWEISS, Ph.D., Associate Plant Pathologist

J. LELAND CRANE, Ph.D. Assistant Mycologist

WALTER HARTSTIRN, Ph.D., Assistant Plant Pathologist

BETTY S. NELSON, Technical Assistant

GENE E. REID, Téchnical Assistant

Section of Aquatic Biology

GEORGE W. BENNETT, Ph.D., Aquatic Biologist and Head

D. HOMER Buck, Ph.D., Aquatic Biologist

R. WELnON LARIMORE, Ph.D., Aquatic Biologist WILLIAM C. STARRETT, Ph.D., Aquatic Biologist ROBERT C. HILTIBRAN, Ph.D., Biochemist

WILliaM F. ChILDERS, Ph.D., A ssociate Aquatic Biologist

DONALO F. HANSEN, Ph.D., Associate Aquatic Biologist

RICHARD J. BAUR, M.S., Research Assistant

DENNIS L. DOOLEY, Téchnical Assistant

MARY Frances MarTin, Technical Assistant

ROBERT F. RANDALL, Ph.D., Technical Assistant

KENNETH R. WALKER, Technical Assistant

C. RUSSELL ROSE, Field Assistant

WARREN U. BRIGHAM, M.S., Junior Technicat Assistant

CONSULTANTS: PARASITOLOGY, NoRMAN D. LEVINE, Ph D Professor of Veterinary Parasitotogy and Veterinary Research, University of Illinois; WILDLIFE RESEARCH, WILLARD D. KLIMSTRA, Ph.D., Professor of Zoology and Director of Cooperative Wildtife Research, Southern Illinois University; STATISTICS, HORACE W. NORTON, Ph.D., Professor of Statistical Design and Analysis, University of Illinois; ENTOMOLOGY, GiLBERT P. WALDBAuER, Ph.D., A ssociate Professor of Entomology, University of Illinois.

\section{Sectian of Faunistic Surveys and}

PIILIP W. SMITH, Ph.D. Taxonomist and Head

WAllaCe E. LABERGE, Ph.D., Taxanamist

MILTON W. SANDERSON, Ph.D., Taxonomist

LEWIS J. STANNARD, JR., Ph.D., Taxonomist

ROBERT W. POOLE, Ph.D., A ssistant Taxanomist mist

DoNalo W. WebB, M.S., Assistant Taxonomist

RODERICK R. IRWIN, Research A filiate

BERNICE P. SWEENEY, Junior Professional Scientist

Section of Wildlife Research

GLEN C. SANDERSON, Ph.D., Wildlife Specialist and Head

RICHARD R. GRABER, Ph.D., Wildlife Specialist

WILLIAM L. ANOERSON, M.A., A ssociate Wildlife Specialist

W. W. COCHRAN, JR., B.S., Associate Wildlife Specialist

WILliaM R. Edwaros, M.S., Associate Witdlife

JACK A. ElLIS, M.S., Associate Wildlife Specialist

RONALD F. LABISKY, Ph.D., Associate Wildlife Speciatist

HARLES M. NixoN, M.S., Associate Wildlife Specialist

StANley L. ETTER, M.S., Assistant Wildlife Specialist Speciatist

G. Blair Joselyn, M.S., A ssistant Wildlife Specialisi

GEORGE B. Rose, Ph.D., Assistant Wildlife Spe-

DAVID R. VANCE, M.S., Assistant Wildtife Specialist

RONALD L. WESTEMEIER, B.S., Assistant Wildlife Specialist

RONALD E. DUZAN, Techrical Assistant

NORMA J. HUBBARD, Technical A ssistant

MARY ANN KJOS, Technical Assistant

HELEN C. SCHULTZ, M.S., Technical Assistant

HILDA WIESENMEYER, Technical Assistant

ELEANORE WILSON, Technical Assistant

ROBERT D. CROMPTON, Field Assistant

JAMES W. SEETS, Laboratory Assistant

Section of Administrative Services

ROBERT O. WATSON, B.S., Administrator and Heacl

\section{Supparting Services}

Wilita G. Dillman, Property Control and Trust Accounts

ROBERT O. ELLIS, Assistant for Operations

LLOYD E. HUFFMAN, Stockroom Manager

J. WILliaM LUSK, Mailing and Distribution Services

MELVIN E SCHWARTZ, Financial Records

JAMES E. SERGENT, Greenhouse Superintendent Publications and Public Relations

OWEN F. GLISSENDORF, M.S., Techriical Editor

ROBERT M. ZEWADSKI, M.S., Assaciate Technical Editor

SHIRLEY MCCleLlaN, Assistant Technical Editor

RICHARD M. SHEETS, Technical Illustrator

Technical Library

Doris F. DOons, B.A., M.S.L.S., Technical Librarian

JEAN ICKES, B.A., M.S.L.S., Assistant Technical Librarian
Insect Identification

FraNk C. BELlRose, B.S., Wildtife Specialist

ROBERT E. GREENBERG, M.S., Assistant Wildlife

WILMER D. ZEHR, Technical Photographer 


\section{CONTENTS}

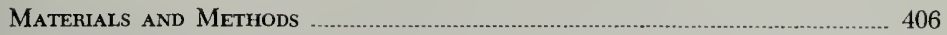

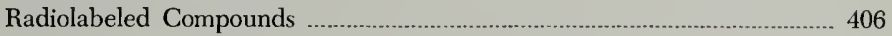

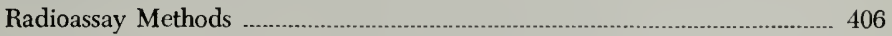

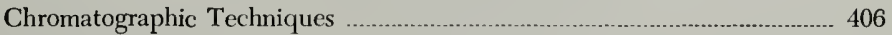

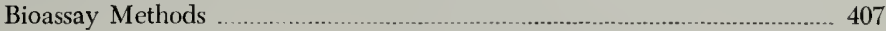

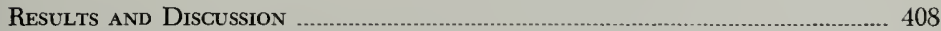

Uptake and Metabolism by Fishes ….................................................. 408

Uptake and Metabolism by Daphnia and Snails ..................................... 411

Uptake and Metabolism by Guppies in a

Daphnia-to-Fish Food Chain

SUMMARY

Literature Cited

This paper is published by authority of the State of Illinois, IRS Ch. 127, Par. 58.12. Keturah A Reinbold is a Research Assistant, Section of Economic Entomology, Illinois Natura History Survey: Dr. Inder P. Kapoor is a Research Assistant, Department of Entomology, University of Illinois; Dr. William F. Childers is an Associate Aquatic Biologist, Section of Aquatic Biology, Illinois Natural History Survey, Dr. Willis $N$. Bruce is an Entomologist, Section of Economic Entomology, Illinois Natural History Survey; and Dr. Robert L. Metcalf is Professor of Zoology, Entomology, and Agricultural Entomology and Head of the Department of Zoology, University of Illinois. 


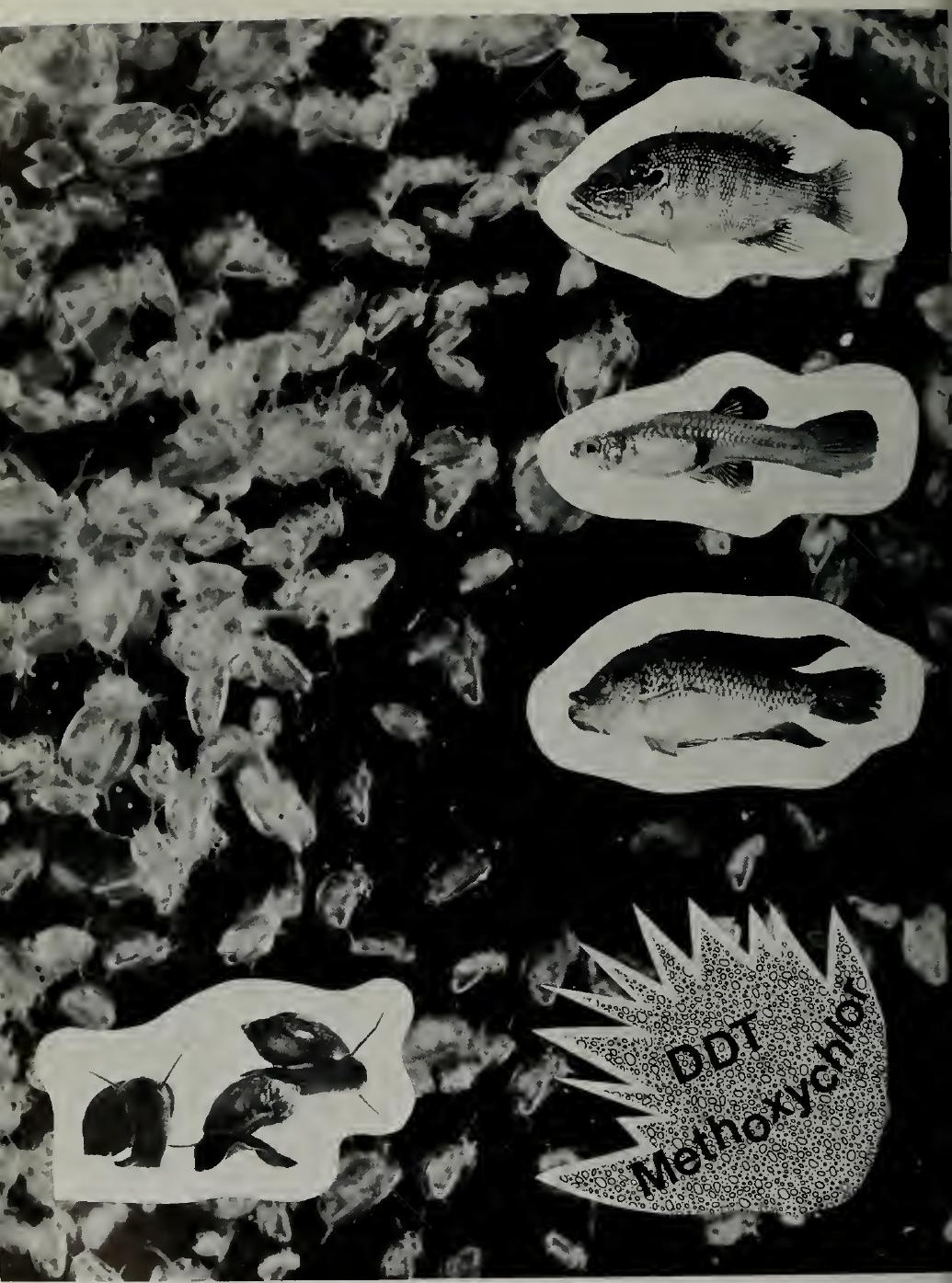

Frontispiece, - Orgonisms and compounds used in this investigotion. On a bockground of dophnio swimming in wot ire (top to bottom) the green sunfish, guppy, tilopio, and snoils. 


\title{
Comparative Uptake and Biodegradability of DDT and Methoxychlor by Aquatic Organisms
}

\author{
Keturah A. Reinbold \\ Inder P. Kapoor \\ William F. Childers \\ Willis N. Bruce \\ Robert L. Metcalf
}

DDT IS SOLUBLE in water to about $0.002 \mathrm{ppm}$, but it is soluble in animal fats to about $100,000 \mathrm{ppm}$. Because DDT possesses such a high lipidto-water partition value and resists attack by multifunction oxidase detoxifying enzymes, this insecticide has become a ubiquitous environmental pollutant and is found in animal tissues everywhere. For example, DDT is present in Lake Michigan bottom muds at about $0.014 \mathrm{ppm}$. It has been found in concentrations of 3-6 ppm in fishes, such as coho salmon and lake trout, taken from Lake Michigan and in even higher concentrations in the tissues of fish-eating birds living near the lake (Harrison et al. 1970:505). DDT used for spruce budworm control in the Yellowstone River system was found to persist in the aquatic environment for more than 2 years (Cope 1961:242-244). Bridges et al. (1963) found concentrations of DDT in a number of organisms in a farm pond treated with $0.02 \mathrm{ppm}$ of DDT. Fish in aquaria have been shown to eliminate DDT very slowly after a single sublethal exposure (Gakstatter \& Weiss 1967:305). Because animals concentrate DDT in their tissues and eliminate it very slowly, aquatic pollution by DDT, whether it results directly from blackfly and mosquito control programs or indirectly from urban treatments for elm bark beetle control or agricultural applications for fruit pests, is particularly deleterious to environmental quality.

The need for a persistent but bio- degradable substitute for DDT is urgent. Methoxychlor is being widely considered as such a substitute, especially for control of blackflies, bark beetles, and fruit and garden pests. It has been reported that, after 28 days of exposure to $0.04 \mathrm{ppm}$ of methoxychlor, bluegills had metabolized or excreted most of the compound which they had taken up. After 56 days no methoxychlor was found in the fish (Kennedy et al. 1970:12). Preliminary studies in a laboratory model ecosystem (Kapoor et al. 1970:1151) indicate that methoxychlor does not accumulate in fishes, as does DDT, but reaches a dynamic equilibrium.

The studies reported in this paper were designed to further test the biodegradability of methoxychlor and to compare in a laboratory aquatic environment (i) the uptake of DDT and methoxychlor directly from water by fishes, from water by crustaceans of the genus Daphnia and by snails of the genus Physa, and from daphnia by guppies in a daphnia-to-fish food chain and (ii) the subsequent elimination of the insecticides from the organisms.

\section{ACKNOWLEDGEMENTS}

We are indebted to several members of the Illinois Natural History Survey staff for their contributions to this investigation. Dr. William H. Luckmann, Head of the Section of Economic Entomology, provided encouragement throughout the study and reviewed the 
manuscript, which was edited by Robert M. Zewadski, Associate Technical Editor. Richard M. Sheets, Technical Illustrator, prepared the graphs and designed the frontispiece, and Wilmer D. Zehr, Technical Photographer, provided most of the photographs. The photograph of the tilapia appearing in the frontispiece was loaned by the Section of Aquatic Biology.

We wish to thank the Natural History Survey and the University of Illinois for the laboratory space and equipment provided for this investigation.

This study was supported in part by funds supplied by U. S. Department of Agriculture Regional Projects NC-85, Reduction of Hazards Associated with the Presence of Insecticidal Chemicals in the Environment, and NC-96, Environmental Implications of Pesticide Usage, both Hatch projects. These funds were administered by the University of Illinois College of Agriculture. The study was also supported in part by U.S. Public Health Service grants FD-00271 and FR-07030.

\section{$16050 \mathrm{EHH}$.}

\section{MATERIALS AND METHODS}

\section{Radiolabeled Compounds}

The investigations were conducted with ${ }^{3} \mathrm{H}$-ring substituted methoxychlor obtained by the procedure of Kapoor et al. (1970:1146). The compound was $99.9+$ percent pure according to our evaluation of it by thin-layer chromatography, and it had a specific activity of $4.81 \mathrm{mC} / \mathrm{mM}$. Ring-labeled ${ }^{14} \mathrm{C}$ DDT was obtained from the World Health Organization of the United Nations, Geneva, Switzerland. The DDT had a specific activity of 5.48 $\mathrm{mC} / \mathrm{mM}$ and a purity of $99.9+$ percent.

\section{Radioassay Methods}

The radioactivity in $1-\mathrm{ml}$ water samples containing radiolabeled compounds was counted in $10 \mathrm{ml}$ of ${ }^{3} \mathrm{H}$ scintillation fluid ( 200 grams of naphthalene, 10 grams of PPO, 0.25 gram of POPOP in dioxane to make 1 liter) in a Beckman S-250 scintillation coun- ter. All organisms used in our investigations were freeze-dried and ground to a powder with a mortar and pestle. Each of three $10-\mathrm{mg}$ portions of each sample of the powdered material was placed in $15 \mathrm{ml}$ of scintillation fluid. The samples were kept in the dark overnight before counting to quench phosphorescence. The radioactivity in each sample was determined by averaging the results of the three counts. Quenching, if any occurred, was corrected for, using the appropriate quench curves. All insecticide concentrations in the organisms were calculated on a dry-weight basis.

\section{Chromatographic Techniques}

Thin-layer chromatography (TLC) was performed in the usual manner using glass plates coated with $0.25 \mathrm{~mm}$ of silica gel. To determine the relative proportions of parent compounds and their metabolites in tilapia (Tilapia mossambica) and green sunfish ( $L e-$ pomis cyanellus), portions of the powdered organisms were extracted with acetonitrile $(2 \mathrm{ml}$ for tilapia, $4 \mathrm{ml}$ for green sunfish). About $0.05 \mathrm{ml}$ of the extract from each sample was spotted on a TLC plate. Non-radiolabeled parent compounds and model metabolites were incorporated as internal standards for cochromatography by spotting them on the plate over the acetonitrile extracts of the fishes. Methoxychlor chromatograms were developed in a solvent system consisting of 3 parts diethyl ether and 1 part petroleum ether (b. p. $60^{\circ}$ to $68^{\circ} \mathrm{C}$ ), and those of DDT in petroleum ether (b. p. $60^{\circ}$ to $68^{\circ} \mathrm{C}$ ) alone.

Radioautographs of the ${ }^{14} \mathrm{C}$-labeled DDT metabolites were made by exposing Eastman Kodak No Screen Medical X-ray film to the developed chromatograms. Black spots which had developed on the film were matched with the incorporated internal standards to determine the identity of the metabolites. The corresponding areas of silica gel were scraped from the 
chromatograms and counted by scintillation counting; from these counts the relative percentages of each parent compound and its metabolites were then calculated. The relative proportions of methoxychlor and its metabolites were determined by scraping appropriate spots or strips of silica gel from the chromatograms and radioassaying them.

\section{Bioossay Methods}

We used cylindrical Pyrex jars 8 inches deep and $81 / 4$ inches in diameter in all of the experiments reported on here. Each jar contained 5 liters of synthetic hard water (Caims 1969:8) and was covered by a plate glass lid. The water was constantly aerated by compressed air bubbling through a glass tube extending down the inside wall of the jar. Both DDT and methoxychlor were added to the water in these jars from standard 0.0025-percent solutions in acetone. The water-insecticide solutions were allowed to equilibrate for 24 hours before any aquatic organisms were placed in the jars.

The animals used were daphnia (Daphnia magna) (hereafter referred to as "daphnia"), snails (Physa sp.) (hereafter referred to as "snails"), tilapia (Tilapia mossambica) (hereafter referred to as "tilapia"), green sunfish (Lepomis cyanellus), and guppies (Lebistes reticulatus). At 2-day, 3-day, or 10-day intervals, the organisms were moved to fresh water or were surface rinsed with clean water and then frozen. Subsequently, the organisms were freeze-dried, powdered, and radioassayed. In all experiments organisms held under the same conditions as were the test animals but not exposed to insecticides were prepared and assayed in the same manner as were the test samples.

Comparative uptake of DDT and methoxychlor from water by two fish species, tilapia and green sunfish, was studied at insecticide levels of 0.001 , 0.003 , and $0.01 \mathrm{ppm}$. The tilapia experiment was duplicated using three fish
(0.6-1.8 grams per fish) in each jar. Two jars of tilapia were used at each of the three levels of each insecticide (12 jars). Only one green sunfish (5-9 grams) was placed in each of three jars at each concentration of each compound (18 jars). One fish was removed from each jar (two tilapia from each insecticide concentration and one green sunfish from each concentration) on the 3rd, 10th, and 31st days, after which the experiment was terminated. On the 10th and 20th days those fishes which remained were transferred to jars containing insecticide concentrations equivalent to those in which the fishes had been placed at the beginning of the experiment.

The uptake of insecticides from water by daphnia (1 gram per jar) was studied at the insecticide levels used in the fish experiments. The daphnia from half of the jars at each concentration of each insecticide were removed on the 3rd day and from the remaining jars on the 6th day. All samples were then radioassayed.

In another experiment tilapia weighing 0.2-1.4 grams each were exposed, five fish per jar in each of five jars for each insecticide, to $0.003 \mathrm{ppm}$ of DDT or methoxychlor for 12 days. At 3-day intervals one fish from each jar was removed for radioassay, and the rest were transferred to water freshly treated with $0.003 \mathrm{ppm}$ of insecticide. After 12 days the remaining fish were moved to water containing no insecticide. Samples of one fish each were then taken after additional periods of $2,5,9,11,12$, and 15 days and assayed for radioactivity to determine the comparative insecticide excretion rates.

Daphnia (2 grams) and snails (1 gram) were exposed together in jars to a level of $0.003 \mathrm{ppm}$ of DDT or methoxychlor for 2,4 , or 6 days. In one series of jars the daphnia and snails were exposed for 2 days, the animals in one jar were removed for radioassay, and the remaining organisms were moved to water without insecticide. They were transferred to fresh water 
without insecticide every 2 days, and a one-jar sample was removed after $1,2,4$, or 6 days. The organisms in another series of jars were transferred to water containing the original level of insecticide after 2 and 4 days. They were also sampled for radioassay after 4 days. After 6 days a sample was removed for radioassay, and the remaining organisms were moved to water without insecticide. Again, they were transferred to fresh water every 2 days and were sampled after 1,3 , or 5 days.

Insecticide uptake in a daphnia-toguppy food chain was studied by holding 2-5 grams of daphnia in water containing $0.003 \mathrm{ppm}$ of DDT or methoxychlor for 48 hours and then feeding them to guppies held in water without any insecticide. Three jars of daphnia exposed to methoxychlor were combined. One-third of these daphnia were analyzed for insecticide content by scintillation counting and the remaining animals were fed to guppies held in two jars, each containing 10 fish. The same procedure was followed with daphnia exposed to DDT and fed to two additional jars of fish. By exposing additional jars of daphnia to the insecticides at 2-day intervals, we repeated the process and fed the fish every other day. Fish were removed from each jar on the 6 th, 8 th, and 20 th days and assayed for radioactivity.

\section{RESULTS AND DISCUSSION}

\section{Uptake and Metabolism by Fishes}

The results of the investigation of the uptake from water of DDT and methoxychlor by tilapia and green sunfish are presented in Table 1 . At the $0.001-p p m$ level the concentration of methoxychlor in tilapia dropped from 0.8 ppm after 3 days of exposure to 0.2 ppm after 10 days, remaining at 0.2 ppm at the end of 31 days. The DDT concentration decreased from $1.3 \mathrm{ppm}$ after 3 days to 0.7 after 10 days; it then increased markedly to $6.8 \mathrm{ppm}$ at 31 days. The same pattern occurred at the higher insecticide levels. The pattern was repeated in the green sunfish, which differed from the tilapia, however, in having lower DDT-to-methoxychlor ratios. These lower ratios may have been the result of the green sunfish's lower proportion of body fat and its consequent smaller capacity for concentrating DDT in fat tissues.

The results show far greater contrasts when we examine the concentration factor (Fig. 1 and 2). While

Table 1. - Comparative uptake fram water of ${ }^{14} \mathrm{C}-\mathrm{DDT}$ and ${ }^{3} \mathrm{H}$-methaxychlor by tilapia and green sunfish.

\begin{tabular}{|c|c|c|c|c|c|c|c|}
\hline \multirow[t]{2}{*}{$\begin{array}{l}\text { Insec- } \\
\text { ticide } \\
\text { Concen- } \\
\text { tration } \\
\text { in Water } \\
\text { in ppm }\end{array}$} & \multirow{2}{*}{$\begin{array}{l}\text { Days } \\
\text { of } \\
\text { Expo- } \\
\text { sure } \\
\text { to } \\
\text { Insec- } \\
\text { ticide }\end{array}$} & \multicolumn{2}{|c|}{$\begin{array}{c}\text { Insecticide } \\
\text { Concentration } \\
\text { in ppm } \\
\text { in Tilapia }\end{array}$} & \multirow[t]{2}{*}{$\begin{array}{c}\text { Ratio } \\
\text { of } D D T \\
\text { to } \\
\text { Methoxy- } \\
\text { chlor }\end{array}$} & \multicolumn{2}{|c|}{$\begin{array}{l}\text { Insecticide } \\
\text { Concentration } \\
\text { in ppm in } \\
\text { Green Sunfish }\end{array}$} & \multirow[t]{2}{*}{$\begin{array}{l}\text { Ratio } \\
\text { of } D D T \\
\text { to } \\
\text { Methoxy- } \\
\text { chlor }\end{array}$} \\
\hline & & $\begin{array}{l}\text { Methoxy- } \\
\text { chlor }\end{array}$ & DDT & & $\begin{array}{l}\text { Methoxy- } \\
\text { chlor }\end{array}$ & DDT & \\
\hline 0.001 & $\begin{array}{r}3 \\
10 \\
31\end{array}$ & $\begin{array}{l}0.8 \\
0.2 \\
0.2\end{array}$ & $\begin{array}{l}1.3 \\
0.7 \\
6.8\end{array}$ & $\begin{array}{r}1.6 \\
3.5 \\
34.0\end{array}$ & $\begin{array}{l}0.8 \\
0.3 \\
0.2\end{array}$ & $\begin{array}{l}0.5 \\
0.6 \\
3.9\end{array}$ & $\begin{array}{r}0.6 \\
2.0 \\
19.5\end{array}$ \\
\hline 0.003 & $\begin{array}{r}3 \\
10 \\
31\end{array}$ & $\begin{array}{l}1.8 \\
0.3 \\
0.6\end{array}$ & $\begin{array}{r}4.4 \\
2.5 \\
12.0\end{array}$ & $\begin{array}{r}2.4 \\
8.3 \\
20.0\end{array}$ & $\begin{array}{l}\cdots \\
0.6 \\
0.6\end{array}$ & $\begin{array}{r}2.2 \\
1.7 \\
10.2\end{array}$ & $\begin{array}{r}\cdots \\
2.8 \\
17.0\end{array}$ \\
\hline $0.0 \mathrm{I}$ & $\begin{array}{r}3 \\
10 \\
31\end{array}$ & $\begin{array}{l}9.0 \\
1.0 \\
2.0\end{array}$ & $\begin{array}{r}16.4 \\
13.9 \\
106.0\end{array}$ & $\begin{array}{r}1.8 \\
13.9 \\
53.0\end{array}$ & $\begin{array}{l}7.4 \\
1.9 \\
2.7\end{array}$ & $\begin{array}{r}\cdots \\
8.6 \\
40.2\end{array}$ & $\begin{array}{r}\cdots \\
4.5 \\
14.9\end{array}$ \\
\hline
\end{tabular}

"All such concentrations were calculated on a dry-welght basis. 


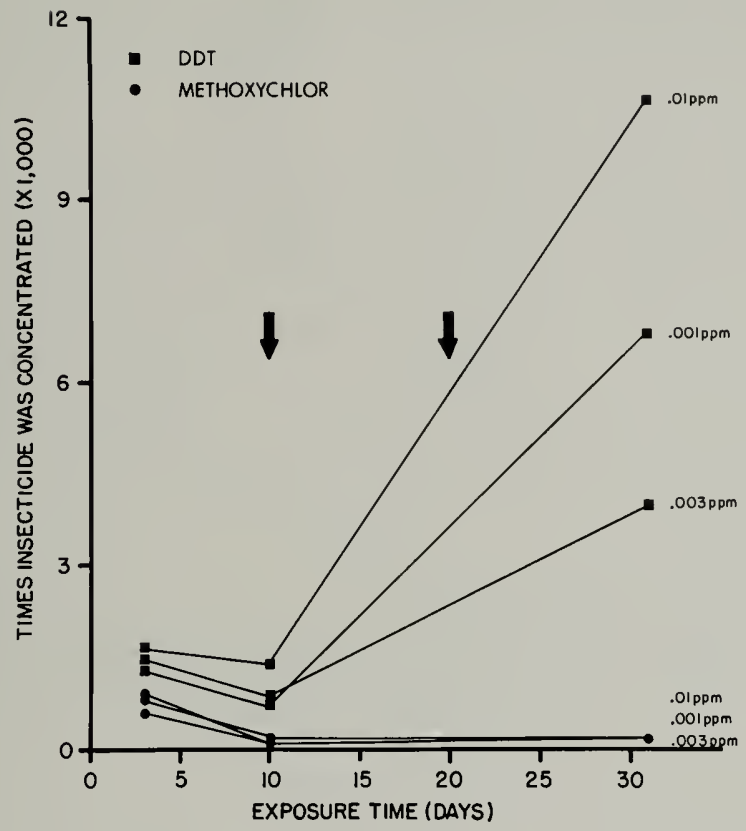

Fig. 1. - Comporative uptake from water of ${ }^{14} \mathrm{C}$-DDT and ${ }^{3} \mathrm{H}$-methaxychlor by tilapia. The vertical orrows indicate the days when fish were tronsferred to jars cantaining insecticide levels equivalent to those which the fish had been placed in at the beginning of the experiment.

the insecticide concentration in methoxychlor-exposed fishes reached an equilibrium, which indicated that the compound was being metabolized and excreted, DDT was increasingly concentrated in the fishes. In tilapia exposed to the $0.01-\mathrm{ppm}$ insecticide level at the end of 31 days, even after the DDT had been concentrated 10,600 times it had not reached a steady state. Furthermore, when tilapia were held in water containing $0.003 \mathrm{ppm}$ of insecticide for 12 days and subsequently were left for 15 days in jars containing water with no insecticide, the radioactive compounds in methoxychlor-exposed fish were rapidly excreted (Fig. 4). At the end of 15 days in uncon- taminated water there was a 10,000 fold difference between the concentrations in tilapia of methoxychlor and of DDT (Table 4).

The metabolic pattern (Table 2) indicates that both fishes metabolized methoxychlor to a greater extent than they did DDT. Tilapia metabolized DDT to a greater extent than green sunfish metabolized it. Tilapia contained DDD as a major metabolite, but the major metabolite of the green sunfish was DDE. Methoxychlor was rapidly metabolized by tilapia, which contained considerably higher proportions of the mono-O-demethylated product [2-( $p$-methoxyphenyl $)-2-(p$-hy droxyphenyl) - 1, 1, 1 - trichloroethane] 
but only slightly greater proportions of trichloroethane] than did the green the bis-O-demethylated metabolite [2, sunfish.

2 - bis - ( $p$-hydroxyphenyl) - 1, 1, 1- The data from these experiments in-

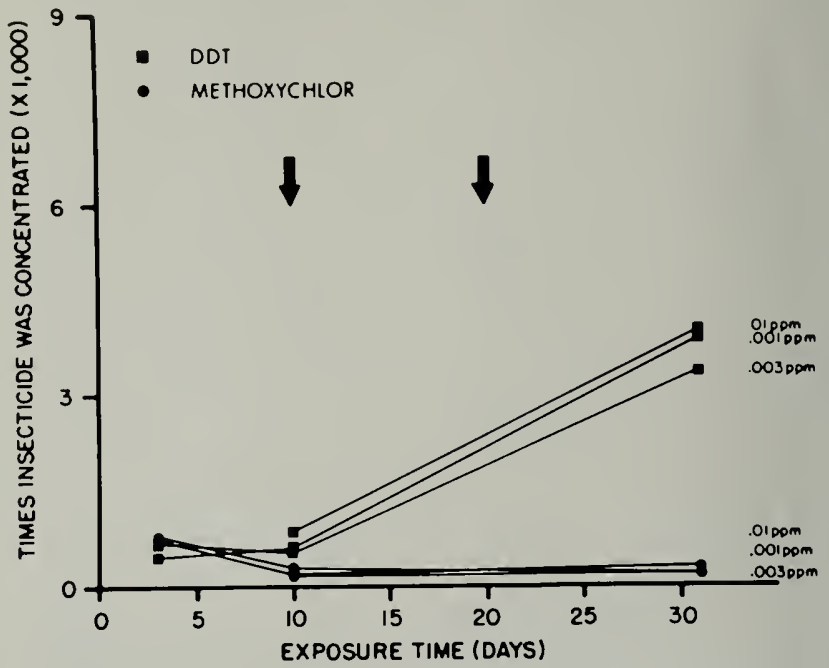

Fig. 2. - Comporotive uptake from water of ${ }^{14} \mathrm{C}$-DDT ond ${ }^{3} \mathrm{H}$-methoxychlor by green sunfish. The verticol orrows indicote the doys when fish were tronsferred to jors contoining insecticide levels equivolent to those which the fish hod been ploced in of the beginning of the experiment.

Toble 2. - Distribution of ${ }^{14} \mathrm{C}$-DDT ond ${ }^{3} \mathrm{H}$-methoxychlor and their metobolites in tilopio ond green sunfish following exposure to woter contoining these insecticides.

\begin{tabular}{|c|c|c|c|c|c|c|c|c|}
\hline \multirow[t]{2}{*}{ Insecticide } & \multirow{2}{*}{$\begin{array}{c}\text { Insec- } \\
\text { ticide } \\
\text { Concen- } \\
\text { tration } \\
\text { in } \\
\text { Water } \\
\text { in ppm } \\
\end{array}$} & \multirow{2}{*}{$\begin{array}{l}\text { Days } \\
\text { of } \\
\text { Expo- } \\
\text { sure } \\
\text { to } \\
\text { Insec- } \\
\text { ticide }\end{array}$} & \multicolumn{6}{|c|}{$\begin{array}{l}\text { Relative Percentages of Insecticides } \\
\text { and Their Metabolites Found in Fishes }\end{array}$} \\
\hline & & & \multicolumn{3}{|c|}{ In Tilapia } & \multicolumn{3}{|c|}{ In Green Sunfish } \\
\hline \multirow[t]{10}{*}{ DDT } & & & DDT & $\underline{\mathrm{DDD}}$ & DDE & DDT & $\underline{\text { DDD }}$ & DDE \\
\hline & 0.001 & 3 & 62.5 & 37.5 & 0.0 & 100.0 & 0.0 & 0.0 \\
\hline & & 10 & 62.0 & 38.0 & 0.0 & 100.0 & 0.0 & 0.0 \\
\hline & & 31 & 66.0 & 29.0 & 5.0 & 91.0 & 1.0 & 8.0 \\
\hline & 0.003 & 3 & 77.0 & 23.0 & 0.0 & 100.0 & 0.0 & 0.0 \\
\hline & & 10 & 56.0 & 37.0 & 7.0 & 100.0 & 0.0 & 0.0 \\
\hline & & 31 & 47.0 & 44.0 & 9.0 & 75.0 & 4.0 & 21.0 \\
\hline & 0.01 & 3 & 76.0 & 24.0 & 0.0 & $\cdots$ & $\cdots$ & $\cdots$ \\
\hline & & 10 & 60.0 & 36.5 & 3.5 & 92.5 & 2.5 & 5.0 \\
\hline & & 31 & 76.0 & 20.0 & 4.0 & 90.0 & 3.0 & 7.0 \\
\hline \multirow[t]{3}{*}{ Methoxychlor } & & & $\mathrm{A}^{\mathrm{n}}$ & $\mathrm{B}^{\mathrm{b}}$ & $\mathrm{C}^{\mathrm{b}}$ & $A^{a}$ & $\mathrm{~B}^{\mathrm{b}}$ & $\mathrm{C}^{\mathrm{b}}$ \\
\hline & 0.01 & 3 & 43.4 & 45.2 & 11.4 & 59.0 & 29.8 & 11.2 \\
\hline & & 31 & 13.9 & 71.3 & 14.8 & 66.3 & 26.9 & 6.8 \\
\hline
\end{tabular}


dicate that methoxychlor is readily biodegradable in tilapia and green sunfish. It seems likely that this insecticide is also biodegradable in other fish species.

\section{Uptake and Metabolism by Daphnia} and Snails

Daphnia also concentrated both methoxychlor and DDT taken up from water. The DDT-to-methoxychlor ratio
(Table 3) in daphnia after 3 days of exposure at the three insecticide levels used in these experiments ranged from 1.8 to 2.5 , a pattern similar to that displayed by the fishes we studied.

When daphnia and snails were held together in jars containing $0.003 \mathrm{ppm}$ of insecticide, daphnia concentrated the two insecticides at about the same rate, but the snails concentrated me-

Toble 3. - Comporotive uptoke from woter of ${ }^{14} \mathrm{C}$-DDT ond ${ }^{3} \mathrm{H}$-methoxychlor by dophnio.

\begin{tabular}{|c|c|c|c|c|}
\hline \multirow{2}{*}{$\begin{array}{l}\text { Insecticide } \\
\text { Concen- } \\
\text { tration } \\
\text { in Water } \\
\text { in ppm }\end{array}$} & \multirow{2}{*}{$\begin{array}{l}\text { Days of } \\
\text { Exposure } \\
\text { to Insec- } \\
\text { ticide }\end{array}$} & \multicolumn{2}{|c|}{$\begin{array}{l}\text { Insecticide } \\
\text { Concentration } \\
\text { in } p p m \text { in Daphnia }\end{array}$} & \multirow{2}{*}{$\begin{array}{c}\text { Ratio of } \\
\text { DDT } \\
\text { to } \\
\text { Methoxychlor }\end{array}$} \\
\hline & & $\begin{array}{l}\text { Methoxy- } \\
\text { chlor }\end{array}$ & DDT & \\
\hline 0.001 & $\begin{array}{l}3 \\
6\end{array}$ & $\begin{array}{r}11 \\
9\end{array}$ & $\begin{array}{l}28 \\
15\end{array}$ & $\begin{array}{l}2.5 \\
1.7\end{array}$ \\
\hline 0.003 & $\begin{array}{l}3 \\
6\end{array}$ & $\begin{array}{l}37 \\
22\end{array}$ & $\begin{array}{l}66 \\
32\end{array}$ & $\begin{array}{l}1.8 \\
1.5\end{array}$ \\
\hline 0.01 & $\begin{array}{l}3 \\
6\end{array}$ & $\begin{array}{l}143 \\
\ldots \ldots\end{array}$ & $\begin{array}{r}316 \\
83\end{array}$ & $\begin{array}{l}2.2 \\
\cdots\end{array}$ \\
\hline
\end{tabular}

All such concentrations were calculated on a dry-weight basis.

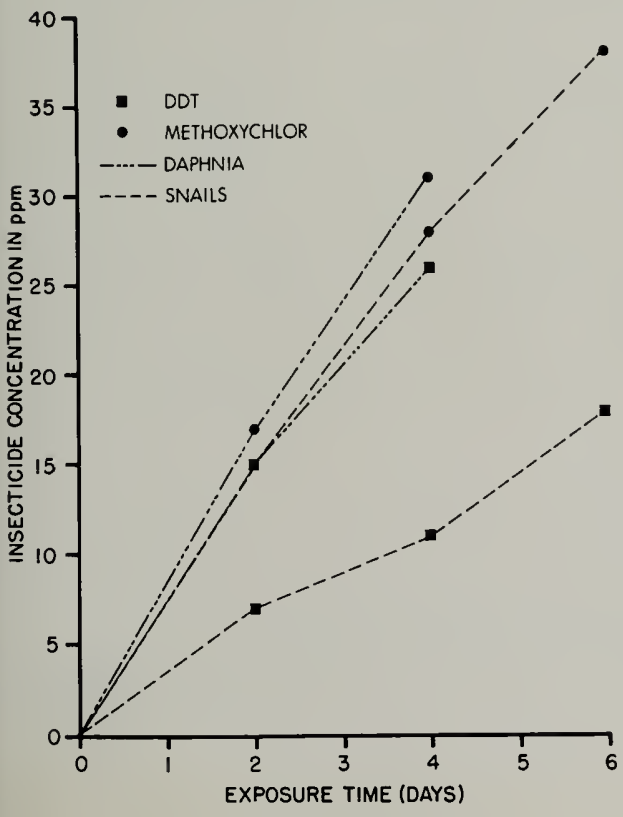

Fig. 3. - Comporotive uptoke of ${ }^{14} \mathrm{C}$-DDT ond ${ }^{3} \mathrm{H}$-methaxychlor by snoils and dophnio following exposure to a 0.003 -ppm insecticide level in woter. 
thoxychlor much more than they concentrated DDT-18 ppm of DDT:38 ppm of methoxychlor after 6 days of exposure to the insecticides (Table 4 and Fig. 3). When daphnia and snails were held in water free of insecticide after exposure to DDT or methoxychlor, both organisms excreted radioactive compounds. Daphnia excreted methoxychlor more rapidly than DDT, while the opposite was true of the snails (Table 4 and Fig. 4). The snails ap- parently cannot readily metabolize methoxychlor and, as a result, retain relatively persistent, high concentrations of that insecticide once they have taken it up. This observation agrees with that of Kapoor et al. (1970:1151). The snails, like the other organisms studied, also tend to retain DDT.

Uptoke and Metabolism by Guppies in a Daphnia-to-Fish Food Choin

The results of the daphnia-to-guppy food chain study are shown in Table 5

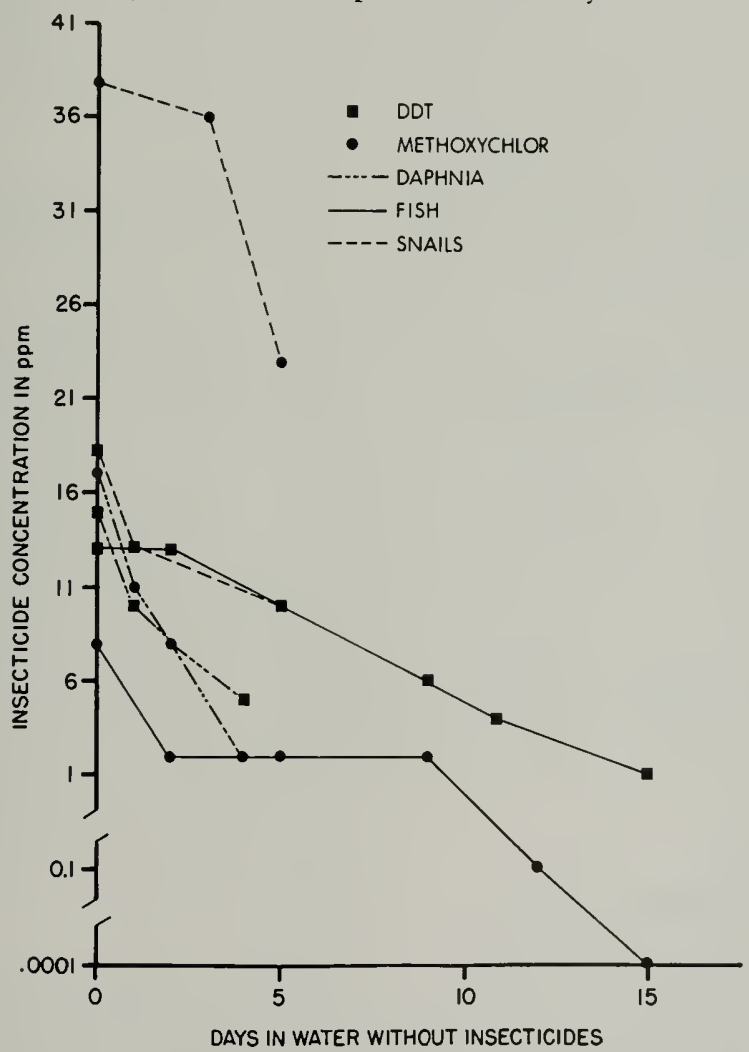

Fig. 4. - Loss of rodioactivity from tilopia, snoils, and dophnia in water without insecticides following exposure to $0.003 \mathrm{ppm}$ of DDT or methoxychlor in woter. Periods of exposure to insecticides: fish, 12 doys; snails, 6 doys; dophnio, 2 doys. 
Toble 5. - Uptoke of ${ }^{14} \mathrm{C}$-DDT ond ${ }^{3} \mathrm{H}$-methoxychlor in a dophnio-to-guppy food chain.

\begin{tabular}{ccccc}
\hline \hline $\begin{array}{c}\text { Insecticide } \\
\begin{array}{c}\text { Concentration } \\
\text { in Daphnia } \\
\text { in ppm }\end{array}\end{array}$ & $\begin{array}{c}\text { Days Fish Fed } \\
\text { on Daphnia } \\
\text { Exposed to } \\
\text { Insecticide }\end{array}$ & $\begin{array}{c}\text { Insecticide } \\
\text { Concentration } \\
\text { in Fish } \\
\text { in ppm }\end{array}$ & $\begin{array}{c}\text { Rate of } \\
\text { Insecticide } \\
\text { Uptake } \\
\text { From Food } \\
\text { By Fish } \\
\text { ppm in Fish }\end{array}$ & $\begin{array}{c}\text { Ratio of Rates } \\
\text { of Uptake } \\
\text { by Fish, } \\
\text { DDT to } \\
\left.\begin{array}{c}\text { Methoxychlor } \\
\text { ppm in Daphnia }\end{array}\right)\end{array}$ \\
\hline $\begin{array}{c}\text { Methoxychlor } \\
22.6\end{array}$ & 6 & 0.14 & 0.006 & $\ldots$ \\
21.3 & 8 & 0.07 & 0.003 & $\ldots$ \\
21.7 & 20 & 0.17 & 0.008 & $\ldots$ \\
DDT & & & & \\
25.1 & 6 & 3.10 & 0.124 & 21.0 \\
25.9 & 8 & 3.69 & 0.143 & 48.0 \\
26.6 & 20 & 7.80 & 0.293 & 38.0 \\
\hline
\end{tabular}

all such concentrations were calculated on a dry-weight basis.

and Fig. 5. There was little difference in the uptake of the two insecticides from water by the daphnia. However, when the daphnia entered the food chain, the methoxychlor content in the

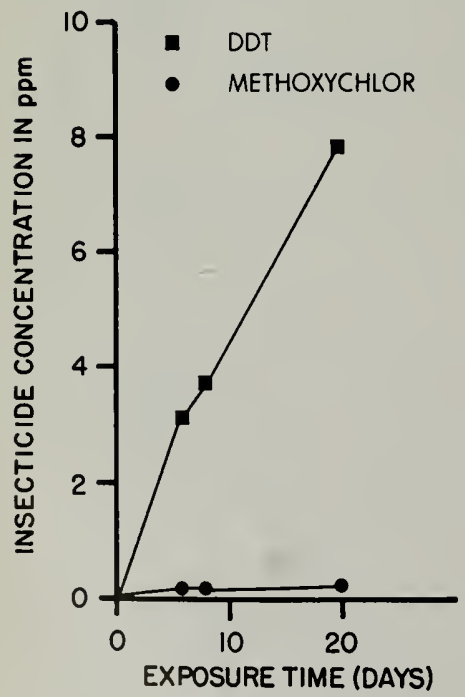

Fig. 5. - Uptoke of ${ }^{14} \mathrm{C}$-DDT ond ${ }^{3} \mathrm{H}$-methoxychlor by guppies in o dophnio-to-guppy food choin. The dophnio were held in woter contoining 0.003 pPm of DDT or methoxychlor for 48 hours before being fed to the fish. fish rapidly reached a steady state, while the concentration of DDT continued to increase. From the 6th to the 20th day the methoxychlor level in the guppies increased only from 0.14 to $0.17 \mathrm{ppm}$, but the DDT level increased from 3.10 to $7.80 \mathrm{ppm}$. The differences in concentration of the two compounds are shown by the relative values of the rates of uptake by the fish from the daphnia (column 4 of Table 5 ) and by the ratios of the rates of uptake (column 5). The difference in accumulation is due to the presence of alkoxy groups on the aryl rings in methoxychlor, which cause it, unlike DDT, to be subject to attack by multifunction oxidases of the fish and, therefore, to be rapidly metabolized and excreted.

In general, our investigations show that methoxychlor appears to be readily biodegradable in fishes and in some, though not all, other aquatic organisms. Thus, it seems to be a safer insecticide than DDT to use in or near aquatic environments.

\section{SUMMARY}

Comparative studies were made of the uptake and metabolism by three species of fishes, by daphnia, and by a snail of radiolabeled methoxychlor and DDT. Tilapia and green sunfish exposed over a 31-day period to the 
radiolabeled insecticides at levels of $0.001,0.003$, and $0.01 \mathrm{ppm}$ in water concentrated DDT as much as $10,600-$ fold and methoxychlor about 200-fold. However, when tilapia were transferred to water with no insecticide following 12 days of exposure to $0.003 \mathrm{ppm}$ of insecticide in water, the residues of methoxychlor decreased within 15 days from $8 \mathrm{ppm}$ to $0.0001 \mathrm{ppm}$ and DDT from 13 to $1 \mathrm{ppm}$, a 10,000 -fold difference between the concentrations of DDT and methoxychlor.

Significant differences were found between the rates at which tilapia and green sunfish metabolized DDT and methoxychlor. Tilapia metabolized DDT to a greater extent and contained DDD as a major metabolite, while green sunfish contained only small amounts of DDD. Tilapia also metabolized methoxychlor more rapidly than green sunfish metabolized it and contained higher amounts of mono- and bis-phenols produced by $\mathrm{O}$-demethylation.

Daphnia in water containing DDT or methoxychlor concentrated DDT at nearly the same rate at which they concentrated methoxychlor to about twice that rate. When daphnia containing either radiolabeled DDT or methoxychlor were fed to guppies to complete a food chain, DDT was rapidly concentrated in the fish, reaching levels of about $8 \mathrm{ppm}$ in 20 days, while methoxychlor concentrations never rose beyond $0.17 \mathrm{ppm}$. Thus, methoxychlor appears readily biodegradable in fishes. However, the snail used in this investigation could not rapidly metabolize either DDT or methoxychlor and accumulated both to high levels.

\section{LITERATURE CITED}

Bridges, W. R., B. J. Kallman, and A. K. Andrews. 1963. Persistence of DDT and its metabolites in a farm pond. American Fisheries Society Transactions 92(4): $421-427$.

CaIrns, John, JR. 1969. Fish bioassays-reproducibility and rating. Revista de Biologia $7(1-2): 7-12$.

Cope, Oliver B. 1961. Effects of DDT spraying for spruce budworm on fish in the Yellowstone River system. American Fisheries Society Transactions 90(3):239-251.

Gaxstatter, JaCk H, and Charles M. WEISS. 1967. The elimination of DDT-CI4, dieldrin-C ${ }^{14}$, and lindane-C ${ }^{14}$ from fish following a single sublethal exposure in aquaria. American Fisheries Society Transactions $96(3): 301-307$.
Harrison, H. L., O. L. Loucks, J. W. Mitchell, D. F. Parkhurst, C. R. Tracx, D. G. WATTS, and V. J. YANnACone, JR. 1970. Systems studies of DDT transport. Science $170(3957): 503-508$.

Kapoon, INder P., Robert L. Metcalf, Robert F. Nystrom, and Gurcharan K. SANGHA. 1970. Comparative metabolism of methoxychlor, methiochlor, and DDT in mouse, insects, and in a model ecosystem. Agricultural and Food Chemistry Journal $18(6): 1145-1152$.

KenNedy, Harry D., Lafayette L. Eller, and David F. Walsh. 1970. Chronic effects of methoxychlor on bluegills and aquatic invertebrates. U.S. Department of the Interior, Bureau of Sport Fisheries and Wildlife Technical Paper 53. 18 p. 


\section{A}

Acctonitrile, 406

B

Bioassay methods, 407-408

Bluegill, 405

\section{C}

Carbon ${ }^{1+}\left({ }^{11} \mathrm{C}\right), 406$

Chromatography

cochromatography, 406

thin-layer chromatography, 406

Coho salmon, 405

Daphnia magna, 405, 407-408, 411-415

DDT

elimination or excretion of, $405,412,413$, 415

environmental pollution by, 405

Lake Michigan pollution by, 405

metabolism of by organisms, 409, 410, 415

metabolites of

DDD, 409, 410, 415

DDE, 409,410

radiolabeled, 406, 414

rolubility in water and fats of, 405

specific activity of radiolabeled, 406

uptake and/or accumulation of by organisms

birds, 405

coho salmon, 405

daphnia, 411, 412, 414, 415

grecn sunfish, 408, 410, 414-415

guppy, 414,415

lake trout, 405

snail, 411, 412, 413, 415

tilapia, $408,409,412,415$

use of in control programs

blackfly, 405

elm bark beetle, 405

mosquito, 405

spruce budworm, 405

Ycllowstone River system pollution by, 405

Dioxane, 406

\section{E}

Ecosystem, laboratory model, 405

Ether

diethyl, 406

petrok:1m, 406

$\mathrm{F}$

Fishes (see under individual species)
Food chain, 405, 408, 413-414, 415

Freeze-dried organisms, 406, 407

\section{G}

Green sunfish (see Lepomis cyanellus)

Guppy (sce Lebistes reticulatus)

\section{$\mathrm{H}$}

3H, 406

I

Insecticide (see DDT and methoxychlor)

Internal standard, 406

\section{L}

Lake Míchigan, 405

Lake trout, 405

Lebistes reticulatus, 405, 407, 408, 413-414, 415

Lepomis cyanellus, 406, 407, 408-411, 414-415

\section{M}

Metabolism (see DDT and methoxychlor)

Metabolites ( sec also DDT and methoxychlor) model metabolites, 406

Methoxychlor

biode gradability of, $405,411,414,415$

elimination or excretion of, $405,409,412$, 413

dynamic equilibrium (steady state) of, 405 , 409, 414

metabolites of

2-(p-methoxyphenyl)-2-

( $p$-hydroxyphenyl)-1,1,1-

trichloroethane, 409, 410,415

2,2-bis-( $p$-hydroxyphenyl)-

1,1,1-trichloroethane, 410,415

metabolism of by organisms, 405, 409-410, 413,415

radiolabeled, 406, 414

specific activity of radiolabeled, 406

suhstitute for DDT, 405, 414

uptake and/or accumulation of by organisms

daphnia, 411, 412, 414, 415

green sunfish, $408,410,415$

guppy, 414, 415

snail, 411, 412, 413, 415

tilapia, $408,412,415$

Multifunction oxidase enzymes, 405, 414

\section{N}

Naphthalene, 406 


\section{$p$}

Physa, 405, 407, 411, 412, 413, 414, 415

Phosphorescence, 406

POPOP, 406

$\mathrm{PPO}, 406$

\section{Q}

Quench curves, 406

$\mathbf{R}$

Radioassay, 406, 407, 408

Radioautograph, 406

Radiolabeled insecticide (see under DDT and methoxychlor)

S

Scintillation counter, 406
Scintillation counting, 406, 407, 408

Scintillation fluid, 406

Silica gel, 406,407

Snail (see Pliysa)

Specific activity (see under DDT and methosychlor)

Snythetic hard water, 407

\section{T}

Tilapia mossambica, 406, 407, 408-411, $412,414,415$

\section{U}

Uptake of insecticides (see under DDT and methoxychlor)

\section{Y}

Yellowstone River system, 405 






\section{Some Publications of the ILLINOIS NATURAL HISTORY SURVEY}

\section{BULLETIN}

Volume 29, Article 3.-Hybridization of Four Species of Sunfishes (Centrarchidae). By William F. Childers. September, 1967. 55 p., frontis., 2 fig., color plate, bibliogr., index.

Volume 29, Article 4,-The Thrips, or Thysanoptera, of Illinois. By Lewis J. Stannard. Iay, 1968. 338 p., frontis., 310 fig., biblingr., index.

Voltune 30, Article 1.-Largemonth Bass and Other Fishes in Ridge Lake, lllinois, 194 I1963. By George W. Bennett, H. Wickliffe Adkins, and W'illian F. Childers. September, 1969. 67 p., 10 fig., bibliogr., index.

Volune 30, Article 2.-Dynamics of OneSpecies Populations of Fishes in Ponds Subjected to Cropping and Additional Stocking. By D. Homer Buck and Charles F. Thoits 1II. March, 1970. 97 p., 10 fig., billiogr., index.

Volume 30, Article 3.-Migrational Behavior of Mallards and Black Ducks as Determined from Banding. By Frank C. Bellrose and Robert D. Crompton. September, 1970. 68 p., frontis., 25 fig., bibliogr., index.

Volume 30, Article 4.-Fertilization of Established Trees: A Report of Field Studies. By Dan Neely; E. B. Himelick, and Webster R. Crowley, Jr. September, 1970. 32 p., frontis., 8 fig., bibliogr., index.

Volume 30, Article 5.-A Survey of the Mussels (Unionacea) of the Illinois River: a Polluted Stream. By Willian C. Starrctt. February; 1971. 137 p., 17 fig., bibliogr., inclex.

\section{BIOLOGICAL NOTES}

62.-Nightlighting: Its Use in Capturing Pleasants, Prairic Chickens, Bobwhites, and Cottontails. By Ronald F. Labisky. October, 1968. 12 p., 8 fig., bibliogr.

63.-Seleeted Minerals in Soils, Plants, and Pheasants: An Ecosystem Approach to Understanding Pleasant Distribution in Illinois. By Robert L. Jones, Ronald F. Labisky, and IVilliam L. Anderson. Dccember, 1968. 8 p., I fig., bibliogr.
64.-The Value of In Vitro Fungieide Tests. By Dan Neely. January, 1969. 8 p., bibliogr.

65.-Trends in Pheasant Abundance in Illinois: 1958 to 1968. By Ronald F. Labisky. May, 1969. 8 p., 4 fig., bibliogr.

66.- Tree and Slirub Hosts of Vertieillium albo-atrum. By E. B. Himelick. July, 1969. 8 p., bibliogr.

67.-Concentrations of Chemical Elements in Pheasant Tissues. By William L. Anderson and Peggy L. Stewart. April, 1970. 15 p., billiogr.

68.-Illinois Bircls: Mimidae. By Richard R. Graber, Jean W. Graber, and Ethelyn L. Kirk. September, 1970. 38 p., 32 fig., bibliogr.

69.-The Life History of the Dusky Darter, Percina sciera, in the Embarras River, Mllinois. By Lawrence M. Page and Philip IV. Sunith, September, 1970. 15 p., 11 fig., bibliogr.

70.-An Ecological Study of Four Darters of the Genus Pcrcina (Percidae) in the Kaskaskia River, lllinois. By David L. Thomas. December, 1970, 18 p., 11 fig., bibliogr.

71.-A Synopsis of Common and Economic Illinois Ants, with Keys to the Cenera (Hymenoptera, Fonmieidae). By Herbert H. Ross, George L. Rotramel, and Wallace E. LaBerge. January, 1971. 22 p., 27 fig., bibliogr.

72. - The Use of Fictor Analysis in Modeling Nitural Communities of Plants and Animals. By Rolert IV. Poole. Fibruary, 1971. 14 p., 14 fig., bibliogr.

\section{CIRCULAR}

46.-1llinois Trees: Their Diseases, By J. Cedric Carter. June, 1964. (Third printing, with alterations.) 96 p., frontis., 89 fig.

49.-The Dunesland Heritage of Illinois. By Herbert H. Ross (in cooperation with Illinois Department of Conservation). August, 1963. 28 p., frontis., 16 fig., bibliogr.

51--1llinois Trees: Selection, Planting, and Care. By J. Cedric Carter. August, 1966. 123 p., frontis., 108 fig.

52.-Fertilizing and Watering Trees. By Dan Neely and E. B. Himelick. December, 1968. (Second printing.) 20 p., 9 fig., bibliogr.

53.-Dutch Elm Disease in lllinois. By J. Cedrie Carter. October, 1967. 19 p., frontis,, 17 fig.

\section{List of available publications mailed on request}

No charge is made for publications of the Illinois Natural History SURvey. A single eopy of most publications will be sent free to anyone requesting it until the supply becomes low. Costly publications, more than one copy of a publication, and publications in short supply are subjects for special correspondence. Such correspondence should identify the writer and explain the use to be made of the publication or publieations.

\footnotetext{
Address arders and correspondence to the Chief, IIlinais Natural Histary Survey

Natural Resources Building, Urbana, Illinois 61801
} 